\title{
Communities Make the Difference
}

\author{
Subhash C Parija \\ Pondicherry Journal of Nursing (2019): 10.5005/jp-journals-10084-12136
}

Ever since the World AIDS Day was first observed three decades ago, ${ }^{1}$ the onus has been largely on the progress made in the health sector aimed at enforcing measures to prevent and treat HIV. It is certain that in the realms of public health, communities represent a strong and unique force that would propel the success of the HIV response. ${ }^{2}$

It is in this context that the World Health Organization strongly urges the countries to resort to community-based HIV testing, prevention, treatment, and the much needed care that includes comprehensive nursing care. ${ }^{3}$

As we prepare ourselves to commemorate the World AIDS Day this year, it must be said in all fairness that women continue to shoulder a huge burden of the HIV/AIDS epidemic. ${ }^{4}$ It is in this context that women of India warrant greater control over their sexual as well as reproductive health. ${ }^{5}$ Nursing professionals should focus on this and reach out to women in particular.

Nurses essentially need to occupy the center stage of the global response. This includes the participation of women in research, nodal efforts aimed at policy making, and more importantly community-based programs that are all enabled by a discerning nursing professional. ${ }^{6}$

The need of the hour is delivering an integrated sexual and reproductive health package that necessarily includes HIV prevention, besides therapeutic modalities, and nursing care for adolescents, young, and the vulnerable population. ${ }^{7}$ In this context, the role played by the community nurses cannot be undermined, since they need to be adaptable to a variegated work environment prevailing at workplaces. Most significantly, community nurses should learn and practice providing care without having to resort to the resources available in the precincts of a hospital. ${ }^{8}$

Nurses have a huge and committed role to play by embracing the principles of community nursing and they need to don the role of community care managers. ${ }^{9}$ By garnering the power of community, we can bridge the gaps in HIV prevention and response and convincingly end the AIDS epidemic for sure, by year 2030.

Sri Balaji Vidyapeeth, Pillaiyarkuppam, Puducherry, India

Corresponding Author: Subhash C Parija, Sri Balaji Vidyapeeth, Pillaiyarkuppam, Puducherry, India, Phone: +91 413-2616766 , e-mail: vc@sbvu.ac.in

How to cite this article: Parija SC. Communities Make the Difference. Pon J Nurs 2019;12(4):81.

Source of support: Nil

Conflict of interest: None

This is feasible only if we are united in our endeavor, and it is here the communities would make the difference. ${ }^{10}$

To conclude, HIV/AIDS healthcare and the accompanying support could be effectively managed within communities, a fact that needs to be reaffirmed. Reducing the morbidity of HIV transmission transgresses social and cultural barriers and necessarily calls for pronounced structural and functional changes. These changes would mobilize a situation in order to empower the downtrodden and disadvantaged people. They eventually would go a long way in removing stigma. Needless it is to state that nursing professionals in general and particular those professionals practising community health nursing play a huge role.

\section{References}

1. http://www.worldaidsday.org/about/.

2. https://www.ncbi.nlm.nih.gov/books/NBK234574/.

3. https://www.who.int/hiv/topics/vct/about/en/.

4. https://www.ncbi.nlm.nih.gov/pmc/articles/PMC3642364/.

5. https://www.ncbi.nlm.nih.gov/pmc/articles/PMC3038639/.

6. https://www.hindawi.com/journals/anurs/2014/174960/.

7. https://reproductive-health-journal.biomedcentral.com/ articles/10.1186/s12978-019-0709-6.

8. https://online.stu.edu/articles/nursing/whats-importantcommunity-health-nursing.aspx.

9. https://www.ncbi.nlm.nih.gov/pubmed/11398570.

10. https://apps.who.int/iris/bitstream/handle/10665/259638/EndAIDSeng.pdf;jsessionid=B9F083F6788C5AF8319CACE9A48837AA?seque nce $=1$.

(C) The Author(s). 2019 Open Access This article is distributed under the terms of the Creative Commons Attribution 4.0 International License (https://creativecommons. org/licenses/by-nc/4.0/), which permits unrestricted use, distribution, and non-commercial reproduction in any medium, provided you give appropriate credit to the original author(s) and the source, provide a link to the Creative Commons license, and indicate if changes were made. The Creative Commons Public Domain Dedication waiver (http://creativecommons.org/publicdomain/zero/1.0/) applies to the data made available in this article, unless otherwise stated. 